\title{
Cushing syndrome secondary to ectopic adrenocorticotropic hormone secretion from a Meckel diverticulum neuroendocrine tumor: case report
}

\author{
Diana Loreta Paun ${ }^{1,2+}$, Lavinia Vija ${ }^{1 *+}$, Emilia Stan ${ }^{3}$, Alexandra Banica ${ }^{1}$, Elena Bobeica ${ }^{1}$, Dana Terzea ${ }^{1}$, \\ Catalina Poiana ${ }^{1,2}$, Corin Badiu ${ }^{1,2}$ and Sorin Paun ${ }^{2,4}$
}

\begin{abstract}
Background: Ectopic production of adrenocorticotropic hormone (ACTH) by neuroendocrine tumours (NET) is a rare condition, occult presentations often hampering the diagnosis. Although NET are relatively frequent in the ileon and Meckel diverticulum, we describe the first Cushing's syndrome due to ectopic adrenocorticotropic syndrome (CS-EAS) arising from a Meckel diverticulum.

Case presentation: A 44-year-old man was admitted with recent onset of diabetes, myopathy, edema and hypokalemic metabolic alkalosis consistent with Cushing's syndrome. Both basal and dynamic laboratory evaluation suggested CS-EAS. Laboratory testing also showed high serum levels of chromogranin A (CgA) and urinary 5hydroxyindoleacetic acid (5HIAA). Pituitary and neck/thorax/abdomen/pelvis imaging proved to be normal, while somatostatin analogue ( ${ }^{99 m}$ TC-HYNIC-TOC) scintigraphy revealed increased focalized ileum uptake on the right iliac fossa. Pre-operative ketoconazole and sandostatin treatment controlled the hypercortisolism within a month. Pathological analysis of the resected submucosal $1.8 \mathrm{~cm}$ tumour of the Meckel diverticulum and a metastatic local lymph node confirmed a well differentiated neuroendocrine tumour (grade I), whereas immunohistochemistry was positive for ACTH, chromogranin A and synaptophysin. Post-operative clinical and biochemical resolution of Cushing's syndrome was followed by normalization of both $\mathrm{CgA}$ and $5 \mathrm{HIAA}$, which were maintained at the 6 month follow-up.
\end{abstract}

Conclusion: The identification, characterization and follow-up of this rare cause of ectopic ACTH secretion is important in order to assess the long-term prognostic and management.

Keywords: Ectopic Cushing's syndrome, Ectopic ACTH secretion, Meckel diverticulum, Neuroendocrine tumor, Hipokalaemia

\section{Background}

Cushing syndrome (CS), secondary to ectopic adrenocorticotropic hormone secretion (CS-EAS), was reported initially in 1928, while the link between CS and a nonpituitary tumor as a source of EAS was established in 1962 [1], was recently estimated to constitute up to $18 \%$ of all causes of CS [2-8].

\footnotetext{
*Correspondence: vija_Im@yahoo.com

${ }^{\dagger}$ Equal contributors

1"C.I. Parhon" National Institute of Endocrinology, 34-36, Aviatorilor Boulevard, sector 1, 011863 Bucharest, Romania

Full list of author information is available at the end of the article
}

Among the variety of tumours, mostly of neuroendocrine origin, associated with CS-EAS $[2-4,7,8]$, gastroenteropancreatic tumors (GEP NET) represent 9-17 \% [2, 3, $5,9,10]$. Whereas NET arising from Meckel diverticulum are very rare (more than 120 cases described in the literature [11-15], harbouring particular features among ileal neuroendocrine tumours, from our knowledge, CS-EAS from a Meckel diverticulum was not previously described.

We present the first case of an ectopic adrenocorticotropic hormone secretion, from a Meckel diverticulum neuroendocrine tumor.

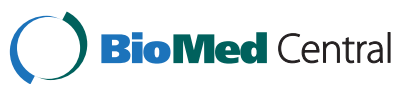

(c) 2015 Paun et al. Open Access This article is distributed under the terms of the Creative Commons Attribution 4.0 International License (http://creativecommons.org/licenses/by/4.0/), which permits unrestricted use, distribution, and reproduction in any medium, provided you give appropriate credit to the original author(s) and the source, provide a link to the Creative Commons license, and indicate if changes were made. The Creative Commons Public Domain Dedication waiver (http://creativecommons.org/publicdomain/zero/1.0/) applies to the data made available in this article, unless otherwise stated. 


\section{Case presentation}

A 44-year-old Caucasian man was admitted in June 2014 to the hospital with recent (5 months) onset of ankle oedema, high blood glucose and low potassium levels $(1.9 \mathrm{mmol} / \mathrm{L})$. Physical examination showed centripetal distribution of the fat tissue with $10 \mathrm{~kg}(15 \%)$ weight loss (BMI $25 \mathrm{~kg} / \mathrm{m}^{2}$ ) over 5 months, moon face, buffalo hump, facial rash, dispersed small bruises on the trunk, generalized muscle weakness and muscle hypotrophy of the lower limbs. The remaining physical examination was normal, including blood pressure levels.

Increased ACTH and cortisol levels, high blood glucose, low potassium and metabolic alkalosis (Table 1) pointed to an ACTH-dependent Cushing syndrome.

The high-dose dexamethasone suppression test $(2 \mathrm{mg}$ of dexamethasone every $6 \mathrm{~h}$ during $48 \mathrm{~h}$ starting at 8 a.m.) showed no cortisol suppression confirming the CS-EAS diagnosis (Table 1). Tumour markers determination showed increased levels of $\mathrm{CgA}$, neuronal specific enolase (NSE), serotonin and 5-hydroxyindoleacetic acid (5-HIAA) (Table 1), all reinforcing an EAS.

Pituitary MRI revealed a pituitary $4 \mathrm{~mm}$ adenoma. Thorax, abdomen and pelvis CT did not reveal any tumour, (data not shown) while adrenal glands were hyperplastic. In this context, a whole body scintigraphy using ${ }^{99 \mathrm{~m}}$ Tc-HYNIC-Tyr ${ }^{3}$-Octreotide (Tektrotyd), previously described as a useful method for diagnosis, staging and follow up of the patients with NETs [16], was performed and revealed increased focal ileum uptake in the right iliac fossa (Fig. 1).

The osteodensitometry showed vertebral osteoporosis with a T-score of -2.9 and Z-score of -2.6 , consistent with secondary osteoporosis.
After the EAS diagnosis, both ketoconazole $(400 \mathrm{mg} / \mathrm{d})$ and sandostatin $(100 \mu \mathrm{gx} 3 / \mathrm{d})$ treatment alleviated hypercortisolism within a month (Fig 2). For the secondary diabetes mellitus, metformin $(850 \mathrm{mgx} 2 / \mathrm{d})$ was prescribed and a good glycaemic control was achieved. Secondary osteoporosis was treated with calcium and vitamin D (900 mg of calcium citrate with $600 \mathrm{IU}$ of choleclaciferol daily).

Laparoscopic abdominal exploration revealed a $12 \mathrm{~cm}$ long Meckel's diverticulum with an irregular shape and a $1.8 \mathrm{~cm}$ nodular tumor mass (Fig. 3). Diverticulectomy with regional lymph node resection was elected, while intraoperative small bowel inspection revealed no luminal damage. Pathological analysis of the resected submucosal $1.8 \mathrm{~cm}$ tumour of the Meckel diverticulum confirmed a well differentiated neuro-endocrine tumour (grade I), whereas immunohistochemistry was positive for ACTH, chromogranin A and synaptophysin; Ki-67 score was < $1 \%$ (Fig. 4). There was one local metastatic lymph node.

One month as well as 6 months post-operatively, plasmatic cortisol, ACTH and tumoral markers (CgA, 5HIAA) were within normal limits (Fig. 2, Table 1).

\section{Conclusions}

Neuroendocrine tumors in Meckel's diverticulum resemble to ileal NET in their biological behavior more than to appendiceal NET. It was recently reported that $77 \%$ of Meckel diverticulum tumors present histological characteristics for a neuroendocrine origin, but when compared to ileal tumors, the risk of cancer in the Meckel diverticulum was 70 times higher than any other ileal site [17]. In a review of 104 Meckel's cases of NET, Nies et al. [13] found an incidence 2.5 greater in men, a frequent localization on the tip of the diverticulum and an

Table 1 Laboratory data

\begin{tabular}{llll}
\hline Variable & On admission & After surgery & Reference range, Adults \\
\hline Sodium & 145 & 140 & $135-145 \mathrm{mmol} / \mathrm{L}$ \\
Potassium & 1.9 & 3.7 & $3.5-4.5 \mathrm{mmol} / \mathrm{L}$ \\
$\mathrm{HCO}_{3}^{-}$ & 33 & 26 & $24-32 \mathrm{mmol} / \mathrm{L}$ \\
Blood glucose & 124 & 82 & $70-100 \mathrm{mg} / \mathrm{dl}$ \\
HbA1c & 8.2 & $<\%$ \\
Plasma cortisol & $>61.4$ & 8 & $6.2-19.4 \mu \mathrm{mg} / \mathrm{dl}$ \\
Plasma cortisol After 1 mg DXM O/N & $>61.4$ & $6.2-19.4 \mu \mathrm{mg} / \mathrm{dl}$ \\
After 8 mg 2-d DXM test & $>61.4$ & $6.2-19.4 \mu \mathrm{mg} / \mathrm{dl}$ \\
24 h-urinary cortisol & 736.8 & $58-403 \mu \mathrm{gg} / 24 \mathrm{~h}$ \\
After 8 mg 2-d DXM test & 13300 & & $58-403 \mu \mathrm{gg} / 24 \mathrm{~h}$ \\
ACTH & 487 & 18 & $3-66 \mathrm{pg} / \mathrm{ml}$ \\
Chromogranin A & 229 & 42 & $20-125 \mathrm{ng} / \mathrm{ml}$ \\
5HIAA & 17 & & $1-10 \mathrm{mg} / 24 \mathrm{~h}$ \\
NSE & 33 & 27 & $0-12 \mathrm{ng} / \mathrm{ml}$ \\
Serotonin & 188 & & $40-400 \mathrm{ng} / \mathrm{ml}$ \\
\hline
\end{tabular}




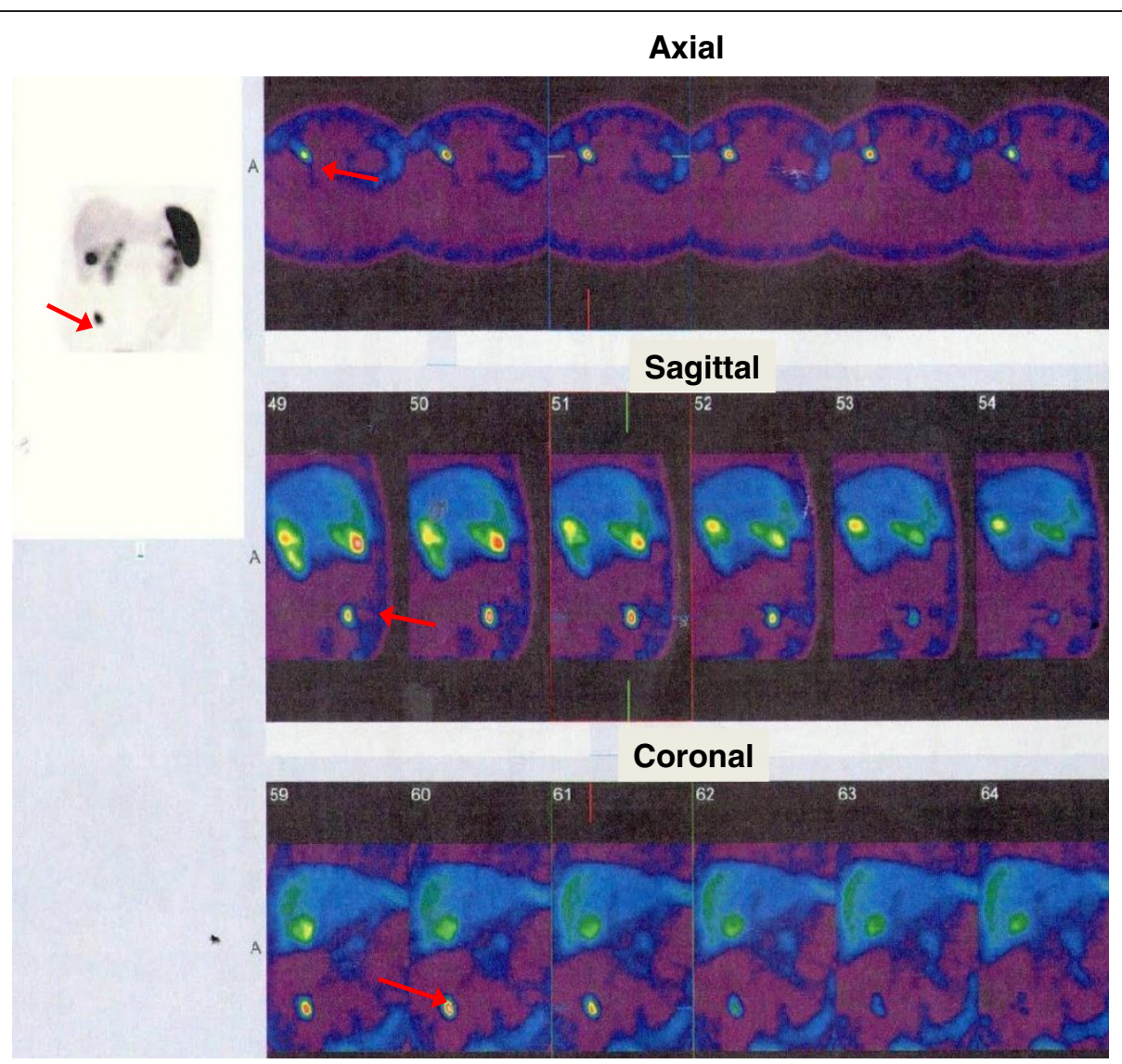

Fig. 1 Whole body scan with somatostatin analogue, ${ }^{99 \mathrm{~m}} \mathrm{TC}-\mathrm{HYNIC}-\mathrm{TOC}$ (Tektrotyd), showing a single nodular region in the inferior third of the right iliac fossa (red arrow)

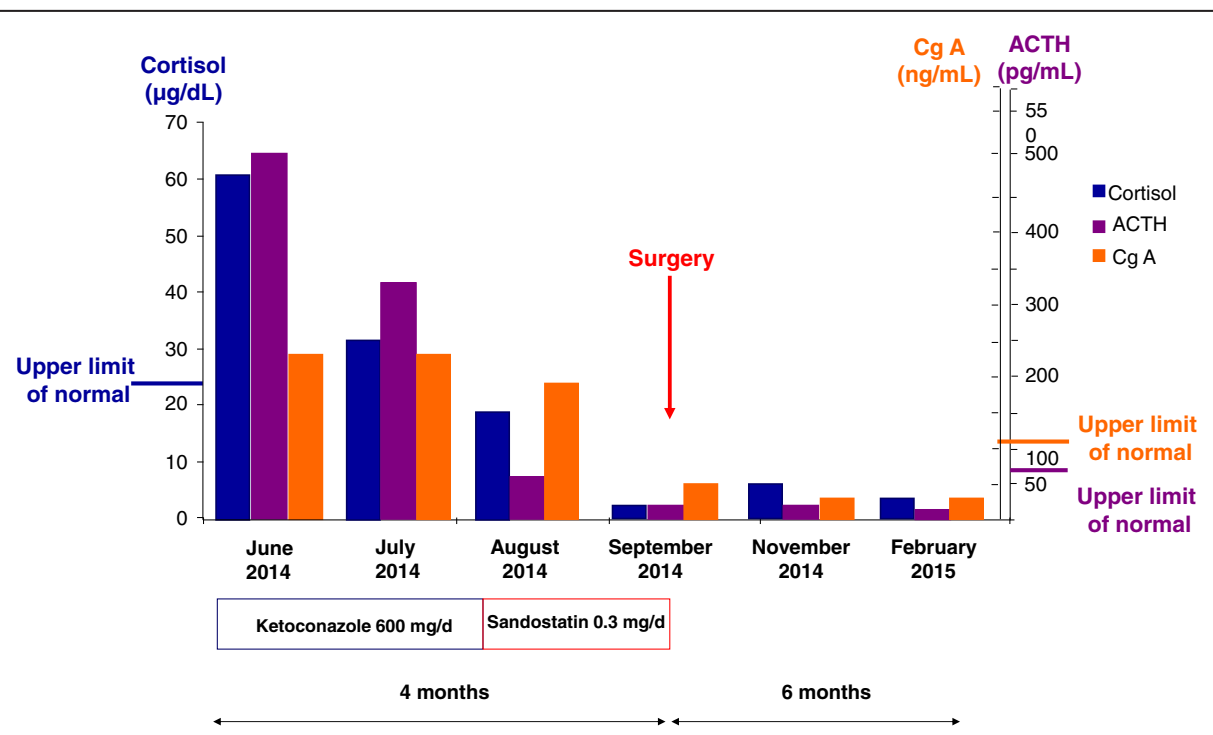

Fig. 2 Histogram of plasmatic cortisol, ACTH and CgA levels evolution during medical treatment (with ketoconazole and sandostatin), as well as after the surgical resection of the Meckel diverticulum tumour and during 6 month follow-up. ACTH-adrenocorticotropic hormone; CgA-chromogranin A 


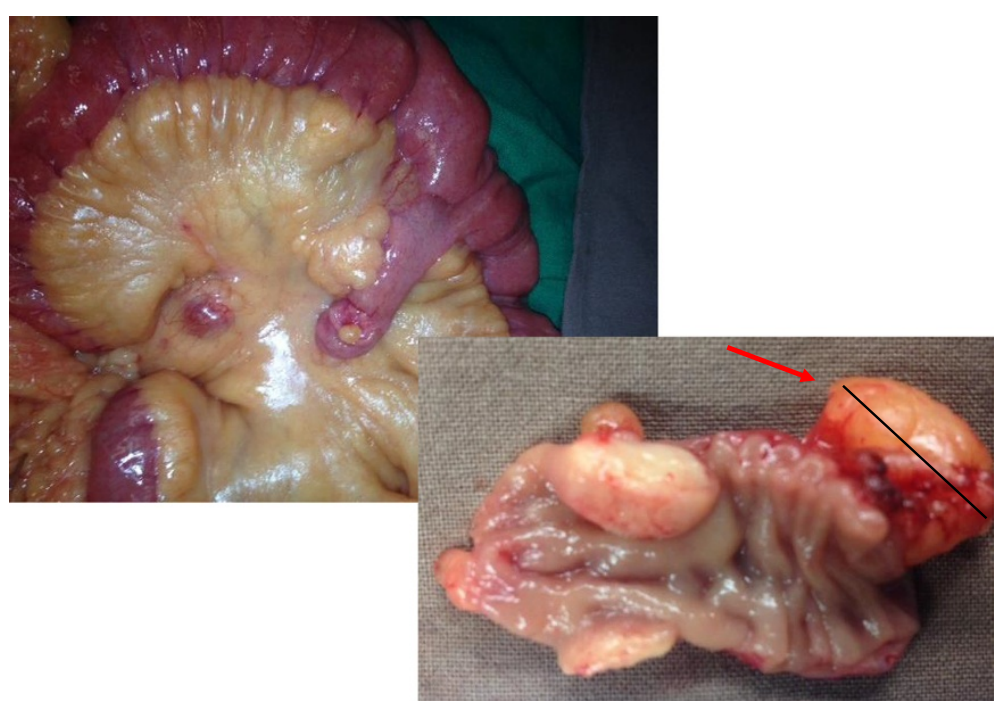

Fig. 3 Long Meckel diverticulum with 1.8/1 cm submucosal nodular tumor (red arrow)

exceptional association with metastatic carcinoid syndrome of less than $2 \mathrm{~cm}$. The presented case had a less than $2 \mathrm{~cm}$ well differentiated NET with local lymph node extension. Jejuno-ileal NET represent $30-50 \%$ of all small bowel neoplasms, with $72 \%$ survival rates at 5 years for tumours with loco-regional spread [14, 18]. Along with this line, we expect that our patient might follow the same clinical course, or even better, as the histological type corresponded to a well differentiated tumor G1 with Ki67 < $1 \%$.
Ectopic ACTH syndrome produced by a NET from the gastrointestinal tract is extremely rare and only described in isolated case reports. While only five cases of CS-EAS form appendicular NET were reported in the literature [2, 19-22], from our knowledge we present the first case of CS-EAS from a Meckel diverticulum well differentiated NET.

Clinical features of ectopic ACTH syndrome depend on the source of production and rate of ACTH synthesis. Characteristically, these patients have severe
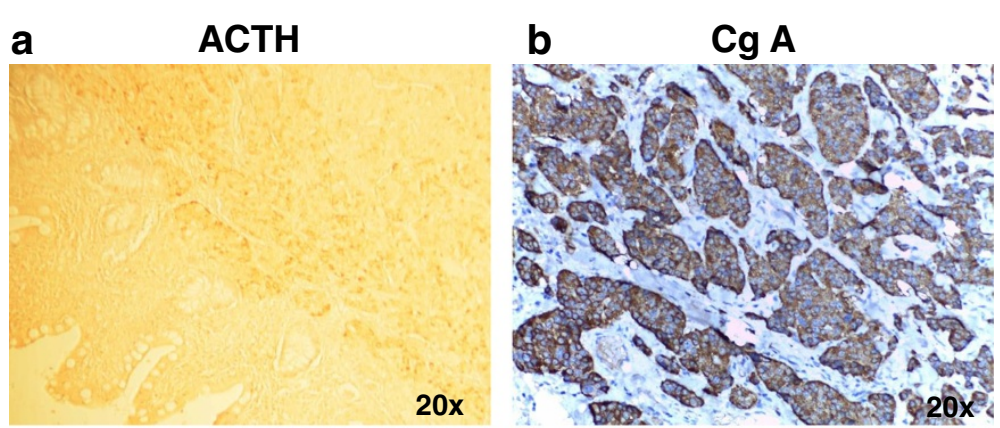

\section{Synaptophysin}
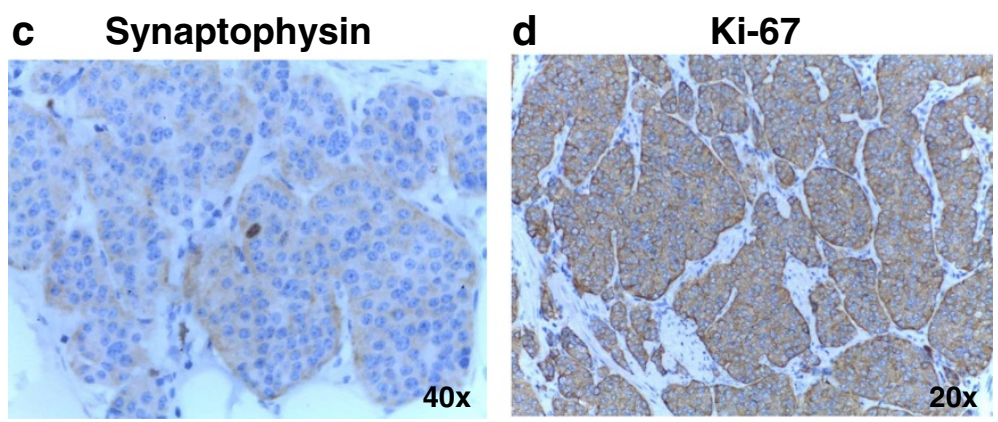

Fig. 4 Tumoral positive immunostaining for ACTH (a), CgA (b), synaptophysin (c) and Ki-67(d) 20x magnification, for a,b,d; 40x magnification for c. ACTH-adrenocorticotropic hormone; CgA-chromogranin A 
hypercortisolemia leading to low serum potassium levels, diabetes, generalized infections, hypertension, and psychosis. Whether rapidly growing tumours, such as small cell lung cancer typically produce profound and sudden onset of symptoms, well defined Cushingoid body habitus changes are noticed in slower growing tumours such as jejuno-ileal NET, as was demonstrated in this patient.

The current case is the first report of a Meckel diverticulum NET-producing ACTH presenting clinically as Cushing's syndrome. The diagnosis was assisted by a positive somatostatin analogue whole body scintigraphy.

Localization of EAS tumours is often challenging as occult tumours have been described in $12-19 \%$ of adult patients [2-5, 23]. Modern cross-sectional imaging (CT and/ or MRI of the neck/thorax/abdomen/pelvis) are recommended as first line investigations [24]. When these are negative, functional imaging techniques in adults (somatostatin analogues scintigraphy, coupled with SPECT/ $\mathrm{CT},{ }^{18} \mathrm{~F}$-DOPA-PET-CT or ${ }^{68} \mathrm{Ga}$-labelled peptides-PET$\mathrm{CT}$ ) brought promising results in the localization of jejuno-ileal NET $[23,25,26]$.

There have been described only two cases of Meckel diverticulum carcinoma with uptake of FDOPA-PET, FDG-PET and somatostatin receptor scintigraphy [26].

Metabolic PET scanning using 18-fluorodeoxyglucose (FDG) was not usually recommended since it has a low sensitivity for jejuno-ileal NET, due to low metabolic activity in G1 tumors. Indeed, the sensitivity of $\mathrm{CT}$ and combined somatostatin analogues scintigraphy in the localization CS-EAS was found to be higher (53 \%) than that of MRI (37 \%) or FDG-PET (35 \%) [27].

In the presented case, the somatostatin analogue scintigraphy allowed the localization of the EAS tumour source. Surgical resection was the definitive and optimal management of this rare condition and led to a complete resolution of symptoms.

Further studies on more cases would be needed in order to evaluate the best follow-up procedure, as well as the long term progression free survival and outcome for patients with this rare localization of ileal neuro-endocrine tumor.

\section{Consent}

Written informed consent was obtained from the patient. A copy of the written consents is available upon request for review by the Journal Editor.

\section{Competing interests}

The authors declare that they have no competing interests.

\section{Authors' contributions}

DLP and LV led the conception and design, acquisition of data, review of literature, and drafted the manuscript. CP, CB and SP critically reviewed the manuscript. DT provided the paraffin embedded samples and advised on the pathology pictures. ES, AB, EB contributed to the patient diagnosis and management and critically reviewed the manuscript. All authors read and approved the manuscript.

\section{Authors' information}

DLP is Associate Professor at "Carol Davila" University of Medicine and Pharmacy, Bucharest, Romania and Endocrinology Consultant at "C. I. Parhon" National Institute of Endocrinology. LV is Practitioner at Department of Nuclear Medecine at "C. I. Parhon" National Institute of Endocrinology. CP and CB are Professors at "Carol Davila" University of Medicine and Pharmacy, Bucharest, Romania and Endocrinology Consultants at "C. I. Parhon" National Institute of Endocrinology.

\section{Acknowledgements}

The authors thank doctor Mirela Gherghe from the Nuclear Medicine Department of the Bucharest Oncology Institute, for having provided us with the scintigraphy images, as well as doctors Ana Maria Stefanescu from National Institute of Pathology and Valentin Enache from the Pathology Department of Floreasca Clinical Emmergency Hospital, for their expertise in pathology and for providing us the photographs of both histology and immuno-histochemistry.

\section{Author details}

" "C.I. Parhon" National Institute of Endocrinology, 34-36, Aviatorilor Boulevard, sector 1, 011863 Bucharest, Romania. "“'Carol Davila" University of Medicine and Pharmacy, Bucharest, Romania. ${ }^{3}$ Braila Department Hospital, Braila, Bucharest, Romania. ${ }^{4}$ General Surgery Department, Bucharest Emergency Hospital, Bucharest, Romania.

Received: 5 March 2015 Accepted: 17 November 2015

Published online: 26 November 2015

\section{References}

1. Meador CK, Liddle GW, Island DP, Nicholson WE, Lucas CP, Nuckton JG, et al. Cause of Cushing's syndrome in patients with tumors arising from "nonendocrine" tissue. J Clin Endocrinol Metab. 1962;22:693-703.

2. Ejaz S, Vassilopoulou-Sellin R, Busaidy NL, Hu MI, Waguespack SG, Jimenez $C$, et al. Cushing syndrome secondary to ectopic adrenocorticotropic hormone secretion: the University of Texas MD Anderson Cancer Center Experience. Cancer. 2011;117(19):4381-89.

3. Ilias I, Torpy DJ, Pacak K, Mullen N, Wesley RA, Nieman LK. Cushing's syndrome due to ectopic corticotropin secretion: twenty years' experience at the National Institutes of Health. J Clin Endocrinol Metab. 2005;90(8): 4955-62.

4. Isidori AM, Kaltsas GA, Grossman AB. Ectopic ACTH syndrome. Front Horm Res. 2006;35:143-56.

5. Isidori AM, Kaltsas GA, Pozza C, Frajese V, Newell-Price J, Reznek RH, et al. The ectopic adrenocorticotropin syndrome: clinical features, diagnosis, management, and long-term follow-up. J Clin Endocrinol Metab. 2006;91(2): 371-7.

6. Salgado LR, Fragoso MC, Knoepfelmacher M, Machado MC, Domenice S, Pereira MA, et al. Ectopic ACTH syndrome: our experience with 25 cases. Eur J Endocrinol. 2006;155(5):725-33.

7. Wajchenberg BL, Mendonca BB, Liberman B, Pereira MA, Carneiro PC, Wakamatsu A, et al. Ectopic adrenocorticotropic hormone syndrome. Endocr Rev. 1994;15(6):752-87.

8. More J, Young J, Reznik Y, Raverot G, Borson-Chazot F, Rohmer V, et al. Ectopic ACTH syndrome in children and adolescents. J Clin Endocrinol Metab. 2011;96(5):1213-22.

9. Aniszewski JP, Young Jr WF, Thompson GB, Grant CS, van Heerden JA. Cushing syndrome due to ectopic adrenocorticotropic hormone secretion. World J Surg. 2001;25(7):934-40.

10. Liddle GW, Nicholson WE, Island DP, Orth DN, Abe K, Lowder SC. Clinical and laboratory studies of ectopic humoral syndromes. Recent Prog Horm Res. 1969;25:283-314.

11. Anderson DJ. Carcinoid tumor in Meckel's diverticulum: laparoscopic treatment and review of the literature. J Am Osteopath Assoc. 2000;100(7):432-4.

12. Lorenzen AW, O'Dorisio TM, Howe JR. Neuroendocrine tumors arising in Meckel's diverticula: frequency of advanced disease warrants aggressive management. J Gastrointest Surg. 2013;17(6):1084-91.

13. Nies C, Zielke A, Hasse C, Ruschoff J, Rothmund M. Carcinoid tumors of Meckel's diverticula. Report of two cases and review of the literature. Dis Colon Rectum. 1992;35(6):589-96.

14. Pape UF, Perren A, Niederle B, Gross D, Gress T, Costa F, et al. ENETS Consensus Guidelines for the management of patients with neuroendocrine 
neoplasms from the jejuno-ileum and the appendix including goblet cell carcinomas. Neuroendocrinology. 2012;95(2):135-56.

15. Poncet $G$, Hervieu V, Walter T, Lepinasse F, Chardon L, Pilleul F, et al. Neuroendocrine tumors of Meckel's diverticulum: lessons from a single institution study of eight cases. J Gastrointest Surg. 2011;15(1):101-9.

16. Artiko V, Sobic-Saranovic D, Pavlovic S, Petrovic M, Zuvela M, Antic A, et al. The clinical value of scintigraphy of neuroendocrine tumors using $(99 \mathrm{~m}) \mathrm{Tc}$ HYNIC-TOC. J Buon. 2012;17(3):537-42.

17. Thirunavukarasu P, Sathaiah M, Sukumar S, Bartels CJ, Zeh H III, Lee KK, et al. Meckel's diverticulum-a high-risk region for malignancy in the ileum. Insights from a population-based epidemiological study and implications in surgical management. Ann Surg. 2011;253(2):223-30.

18. Scherubl H, Jensen RT, Cadiot G, Stolzel U, Kloppel G. Neuroendocrine tumors of the small bowels are on the rise: Early aspects and management. World J Gastrointest Endosc. 2010;2(10):325-34.

19. Beddy D, Larson D. Cushing's syndrome cured by resection of an appendiceal carcinoid tumor. Int J Colorectal Dis. 2011;26(7):949-50.

20. Dobnig H, Stepan V, Leb G, Wolf G, Buchfelder M, Krejs GJ. Recovery from severe osteoporosis following cure from ectopic ACTH syndrome caused by an appendix carcinoid. J Intern Med. 1996;239(4):365-9.

21. Miller T, Bernstein J, Van Herle A. Cushing's syndrome cured resection of appendiceal carcinoid. Arch Surg. 1971;103(6):770-3.

22. Perakakis N, Laubner K, Keck T, Steffl D, Lausch M, Meyer PT, et al. Ectopic $\mathrm{ACTH}$-syndrome due to a neuroendocrine tumour of the appendix. Exp Clin Endocrinol Diabetes. 2011;119(9):525-29.

23. Tabarin A, Valli N, Chanson P, Bachelot $Y$, Rohmer V, Bex-Bachellerie V, et al. Usefulness of somatostatin receptor scintigraphy in patients with occult ectopic adrenocorticotropin syndrome. J Clin Endocrinol Metab. 1999;84(4): 1193-202.

24. Zemskova MS, Gundabolu B, Sinaii N, Chen CC, Carrasquillo JA, Whatley M, et al. Utility of various functional and anatomic imaging modalities for detection of ectopic adrenocorticotropin-secreting tumors. J Clin Endocrinol Metab. 2010;95(3):1207-19.

25. Balogova S, Talbot JN, Nataf V, Michaud L, Huchet V, Kerrou K, et al. 18Ffluorodihydroxyphenylalanine vs other radiopharmaceuticals for imaging neuroendocrine tumours according to their type. Eur J Nucl Med Mol Imaging. 2013;40(6):943-66.

26. Talbot JN, Kerrou K, Missoum F, Grahek D, Aide N, Lumbroso J, et al. 6-[F-18]fluoro-L-DOPA positron emission tomography in the imaging of Merkel cell carcinoma: preliminary report of three cases with 2-deoxy-2[F-18]fluoro-D-glucose positron emission tomography or pentetreotide(111/n) SPECT data. Mol Imaging Biol. 2005;7(4):257-61.

27. Pacak K, Ilias I, Chen CC, Carrasquillo JA, Whatley M, Nieman LK. The role of [(18)F]fluorodeoxyglucose positron emission tomography and [(111)In]diethylenetriaminepentaacetate-D-Phe-pentetreotide scintigraphy in the localization of ectopic adrenocorticotropin-secreting tumors causing Cushing's syndrome. J Clin Endocrinol Metab. 2004;89(5):2214-21.

\section{Submit your next manuscript to BioMed Central and we will help you at every step:}

- We accept pre-submission inquiries

- Our selector tool helps you to find the most relevant journal

- We provide round the clock customer support

- Convenient online submission

- Thorough peer review

- Inclusion in PubMed and all major indexing services

- Maximum visibility for your research

Submit your manuscript at www.biomedcentral.com/submit
C) Biomed Central 